\title{
Is bank-debt maturity contingent on the financial system?
}

Paolo Saona

Business and Economics Department, Saint Louis University - Madrid Campus, Madrid, Spain, and

Eleuterio Vallelado

Financial Economics and Accounting Department, Universidad de Valladolid, Valladolid, Spain

Received 26 September 2013

Revised 19 October 2013

29 January 2014

Accepted 14 March 2014

\begin{abstract}
Purpose - The purpose of this paper is to determine whether bank debt-maturity decisions are conditioned by growth opportunities, the firms' ownership structure, or the institutional environment. Design/methodology/approach - The empirical analysis is undertaken using an unbalanced panel data of Chilean and Spanish firms.

Findings - The results indicate that when banks are not allowed to become stockholders, managers use bank debt-maturity as a corporate governance mechanism. When banks can participate in the ownership of the firms that they finance, short-term bank debt can serve as a substitute for a governance mechanism.

Originality/value - The main contribution of this paper is the analysis of how differences in financial development among countries modify financial decisions by firms.

Keywords Ownership structure, Panel data, Banking regulation, Growth opportunities,

Agency problems, Bank debt-maturity

Paper type Research paper

\section{Introduction}

In the presence of market imperfections, decisions about debt-maturity affect a firm's optimal investment policy. Theory indicates that in the presence of growth opportunities, managers may invest sub-optimally when problems of underinvestment and asset substitution appear (Myers, 1977; Barclay et al., 1995; Morgado and Pindado, 2003; Douglas, 2009). One of the mechanisms to solve these agency problems of debt is the use of short-term bank debt.

Our objective is to determine whether bank debt-maturity decisions are conditioned by the existence of growth opportunities, the firm's ownership structure or the institutional environment in which they operate[1]. Thus, in the same vein as King and Levine (1993), one of our contributions is the analysis of how differences in financial development among countries modify financial decisions by firms. Regulations about banks owning controlling stakes in non-financial firms affect the way those companies use external funds to finance growth opportunities. Those bank-based countries with no restrictions on banks becoming internal shareholders favor financing growth
\end{abstract}

The authors are grateful for the comments by: Pablo de Andrés Alonso, Valentín Azofra Palenzuela, José María Fortuna Lindo, Gabriel de la Fuente Herrero, Félix López Iturriaga, Juan Antonio Rodríguez Sanz, and John Manley. The authors are also grateful to two anonymous referees as well as to the participants at EFA annual meeting. They also thank Catherine Ramberg for her editorial assistance. All remaining errors are the sole responsibility of the authors. 
ARLA

27,2

184 opportunities with long-term funds. In contrast, the restriction on banks becoming internal shareholders leads to a more balanced distribution of banks' funds among all firms with growth opportunities. Therefore, bank regulation modifies the allocation of resources and influences which growth opportunities are financed.

The agency problems of debt relating to growth opportunities can be resolved by shortening the debt-maturity or by including lenders as controlling shareholders. Debt should mature prior to the exercise of the growth opportunities, if the investment is to generate value for the firm. Thus, on the one hand, short-term bank debt mitigates problems of underinvestment and asset substitution. On the other, those companies in which banks are internal shareholders do not need to shorten bank debt-maturity to reduce agency problems. Therefore, bank debt-maturity may be conditioned by the characteristics of the financial system (Alcock et al., 2012; Beck and Levine, 2002; La Porta et al., 1997).

To achieve our goal we compared the bank debt-maturity decisions of firms from Chile and Spain. These two countries have a common legal tradition with financial systems dominated by bank intermediaries. There is an important concentration in the banking sectors, and in the ownership structure of their firms. Moreover, the two countries have similar economic stability during the period of analysis in terms of GDP growth, inflation, and interest rates. However, they differ in the way their financial systems have evolved and in their banking regulation. Chilean banking law forbids bank ownership of non-financial firms, whereas in Spain, there are no limitations on bank ownership of non-financial firms.

The main findings of our research indicate that there are differences in the bank debt-maturity decisions between Spanish and Chilean firms seeking to finance their growth opportunities. In Chile, where banks cannot become internal stockholders, managers are forced to use bank debt-maturity to resolve their problems of underinvestment. In Spain, where banks are able to participate in the ownership of the firms, short-term bank debt loses much of its role as a mechanism of governance.

Thus, non-financial firms can be classified into two groups when they need debt to finance their growth opportunities. In one group are those firms with no shareholding ties with a bank; they need to use short-term bank debt to signal the quality of their projects. In the other group are those companies controlled by a financial institution, which avoid short-term debt due to their ownership ties with a bank.

This paper is organized in five sections. After the introduction, the second section describes our empirical hypotheses and a summary of the main theoretical contributions. The third section describes the sample, variables and methodology used in the empirical analysis. Section four presents the main results, and the final section summarizes the main conclusions.

\section{Theory and empirical hypotheses}

Underinvestment and asset substitution problems appear when a firm finances its new projects with debt. Underinvestment can be alleviated either by using secured debt, or by shortening the debt-maturity so that refinancing can occur before the investment option expires (Barclay and Smith, 1999; Cuñat, 1999; Johnson, 2003). Asset substitution can be mitigated by issuing preferred debt, or by shortening the debt-maturity (Smith and Warner, 1979). Moreover, Flannery (1986) argues that shortening the debt-maturity mitigates the asset substitution problem, since the value of short-term debt is less sensitive to any changes in the value of the firm's assets, and, hence, it will be less undervalued than long-term debt. In addition, these problems can be addressed by the choice of lender. 
Banks are in a better position than arm's-length lenders to reduce managerial discretion because of debt ownership concentration (Denis and Mihov, 2003; Hadlock and James, 2002). However, one of the disadvantages of bank debt is that the lender may ultimately hold excessive control over the firm's decisions - the information monopoly problem (Rajan, 1992). Finally, a firm's financing decisions are affected by the institutional setting. The relevance of bank financing and the maturity choice could be the result of the relative weight that financial markets and intermediaries have in the financial system.

Firms with growth opportunities potentially present greater problems of asymmetric information (Goyal et al., 2002; Myers and Majluf, 1984), greater agency problems between stockholders and lenders (De Andrés et al., 2000), and higher bankruptcy costs (Shleifer and Vishny, 1992; Zou and Adams, 2009). Therefore, firms with growth opportunities should use internal funds for their financing (Hovakimian et al., 2001). However, once their own resources are depleted, firms have to choose the most suitable source of external financing. Bank debt reduces the inefficient liquidation outcome (Zou and Adams, 2009). Short-term bank debt also deals with the undervaluation problem associated with asymmetric information; firms lacking growth opportunities are unable to imitate firms with profitable growth opportunities because of their greater risk of bankruptcy (Akerlof, 1970; Yosha, 1995).

However, the role of debt-maturity should be different when banks are allowed to be stockholders in the firms to which they lend, and to take a controlling stake. In bank-based financial systems banks are firms' main - and, at times, only - source of external financing. Banks usually establish relationships of mutual trust with firms, facilitating the provision of funds to firms with growth opportunities. In this case, the managers do not have to resort to shortening the debt-maturity to avoid underinvestment and asset substitution problems, since the banks can opt to lend money or provide the firm with capital (Demirgüç-Kunt and Maksimovic, 1999).

Based on the arguments above, our first hypothesis is:

H1. Firms with profitable growth opportunities will use short-term bank debt in bank-based countries where banks cannot become internal stockholders of the firms.

The problem of asymmetric information seems particularly significant in the case of firms with low cash flows. The problems of inefficient liquidation (liquidity risk), underinvestment, and undervaluation coincide in those firms with growth opportunities and external financing needs. In this scenario, shareholders may prefer to reduce the debt-maturity to overcome the problems generated by the existence of growth opportunities and the need for external funds at the same time. An exception can occur when banks act as internal shareholders because there is no need to increase bankruptcy costs. Consequently, our second hypothesis postulates that:

H2. Firms with growth opportunities that do not generate sufficient internal funds, and where the banks cannot become shareholders, will use short-term bank debt to mitigate problems of moral hazard.

The firm's agency problems vary depending on its ownership structure (Hart and Moore, 1995; Jensen and Meckling, 1976). When ownership is concentrated, managers have the incentive to choose the debt-maturity that maximizes the firm's value 
ARLA

27,2

186

(Bharadwaj and Shivdasani, 2003; Denis and Mihov, 2003). Short-term bank debt helps to improve the firm's corporate governance. Internal stockholders can signal the quality of their investment projects by shortening bank debt-maturity. However, when banks can participate in the ownership of firms, managers do not need to use short-term debt.

Therefore, our third hypothesis is:

H3. In bank-based financial systems where the banks are forbidden to hold equity in companies, there is a negative relation between ownership concentration and bank debt-maturity. If the bank is simultaneously lender and internal stockholder, the ownership concentration of the firm reduces the agency problems between managers, owners and lenders. The firm does not need to use bank debt-maturity to signal the quality of its growth opportunities.

\section{Sample, variables and methodology \\ Sample}

We tested our hypotheses regarding the relationships between bank debt-maturity, growth opportunities, ownership structure and institutional environment using an unbalanced panel data of quoted firms from Chile and Spain. Both countries share legal systems based on the civil-law regime, show economic stability, and have developed their financial markets in a comparable way. However, whereas Spanish banks can become internal stockholders of non-financial firms, Chilean banks are forbidden such a practice (Bartholdy et al., 1997).

We excluded financial firms, since the nature of their business would distort the results. We also excluded the years in which firms have no debt on the balance sheet, as this situation does not allow us to account for the asymmetric information and agency problems of debt.

Our source of information for Chilean firms was the FECU[2]. Our sample included 148 non-financial firms during the 1991-2001 period, accounting for a total of 1,154 observations. These 148 firms belonged to eight different industries: food, fisheries and agriculture (26); cement and building (ten); real estate properties (seven); transport and telecommunications (12); textile, paper and cellulose (15); utilities and energy (27); services (36); and mining (15).

We had 111 non-financial Spanish firms for the same period, with a total of 823 observations. Our source here was the information published by the Comisión Nacional del Mercado de Valores (National Stock Market Commission). As with the Chilean firms, the Spanish firms were classified according to the industry to which they belong: food, fisheries and agriculture (13); cement and building (22); real estate properties (ten); transport and telecommunications (eight); textile, paper and cellulose (11); utilities and energy (19); services (eight); and mining (20). We consider both samples representative of the Chilean and Spanish corporate sectors.

\section{Variables}

As a measure of bank debt-maturity (our dependent variable), we used the ratio of shortterm bank debt to total bank debt (SBDBD) (Chen et al., 1999; Demirgüç-Kunt and Maksimovic, 1999). Unfortunately, the available data do not allow another classification for bank debt-maturity. To control for the problem that short-term bank debt is often used to finance working capital, we used the ratio of short-term bank debt minus the variation of working capital to total bank debt as a dependent variable (SBDWBD)[3]. 
The following are our independent variables. As a measure of ownership concentration we used the percentage of stocks in the hands of the main stockholder (OWN1)[4]. We also used five dummy variables to account for the nature of the main stockholder: a family (FAMFM); an institutional investor - banks in Spain and mutual funds in Chile - (INSINV); a domestic firm (DOMFM); a multinational firm (MULFM); and a governmental entity (PUBFM). We proxied growth opportunities through the ratio of market value to book value (GO) (Cuñat, 1999; Johnson, 1997, 2003); and as a robustness check, we used the market to equity ratio (GO2) (Jara et al., 2012) measured as the market capitalization over the equity capital at book value[5]. We calculated the need for external funds (DEF) to finance a firm's new investment (Shyam-Sunder and Myers, 1999; Sogorb and López, 2005). Shyam-Sunder and Myers (1999) define financing deficit (DEF) as:

$$
D E F_{i, t}=D I V_{i, t}+I_{i, t}+\Delta W C_{i, t}+R_{i, t-1}-C_{i, t}=\Delta L T D_{i, t}+\Delta E_{i, t}
$$

where $D I V_{i, t}$ is the cash dividend of firm $i$ at time $t ; I_{i, t}$ is the net investment; $\Delta W C_{i, t}$ is the change in working capital; $R_{i, t-1}$ is the current portion of long-term debt at the start of the period; $C_{i, t}$ is the cash flow after interest and taxes; $\Delta L T D_{i, t}$ is the long-term debt issued; and $\Delta E_{i, t}$ is the net equity issued.

We included three interaction variables that relate: the ownership structure of the firm to the existence of growth opportunities $(\mathrm{OWN} 1 \times \mathrm{GOI})$, the growth opportunities to the need for external funds $(\mathrm{GO} \times \mathrm{DEFI})$, and the growth opportunities when the main shareholder is a bank $(\mathrm{GO} \times \mathrm{INSINV})$. The variable $\mathrm{OWN1} \times \mathrm{GOI}$ takes the value observed in OWN1 for all firms with growth opportunities $(\mathrm{GO}>1)$, and 0 otherwise. $\mathrm{GO} \times$ DEFI takes the value of growth opportunities for all firms with external fund needs $(\mathrm{DEF}>0)$, and 0 otherwise; whilst GO $\times$ INSINV takes the value of growth opportunities for those firms where the main shareholder is a bank and 0 otherwise. This variable is not applicable to Chilean firms as bank ownership of non-financial firms is forbidden.

Size, return on assets (ROA), solvency, bankruptcy risk, term structure of interest rates, and growth rate of the GDP were our control variables (Antoniou et al., 2008; Berger et al., 2005; Chen et al., 1999; Ozkan, 2002). We used the logarithmic transformation of firm assets as our measure of firm size (LNTAB). To measure profitability, we calculated the ROA. We measured the bankruptcy risk using two alternative proxies, the Altman's $Z$-Score (Z) (Altman, 1968) and the distance to bankruptcy (BKRISK)[6] (Laeven and Levine, 2009). Debt-to-equity ratio (TDEB) was our proxy for solvency. The term structure of interest rates (TINT) was estimated according to Vallelado and Saona (2011) as the difference between long- and short-term interest rates, and everything was divided by long-term interest rates; the growth of GDP (GGDP) was estimated as the annual growth rate in GDP. Table I offers a description of how the variables are measured.

\section{Methodology}

We performed a descriptive analysis and a variance analysis to identify similarities and dissimilarities in the use of bank debt between Chilean and Spanish firms. In a second stage, we ran a regression analysis applying panel data econometrics. This method was appropriate for our model:

$$
\begin{aligned}
Y_{i, t}= & \beta_{0}+\beta_{1} Y_{i, t-1}+\beta_{2} O W N 1_{i, t}+\beta_{3}(O W N 1 \times G O I)_{i, t}+\beta_{4} G O_{i, t}+\beta_{5}(G O \times D E F I)_{i, t} \\
& +\beta_{6} T_{D E B} B_{i, t}+\beta_{7} L N T A B_{i, t}+\beta_{8} Z_{i, t}+\beta_{9} R O A_{i, t}+\beta_{10} T_{N I} T_{i, t}+\beta_{11} G G D P_{i, t} \\
& +\beta_{12} D U M S E C+\beta_{13} D U M T E M P+\eta_{i}+\varepsilon_{i, t}
\end{aligned}
$$


ARLA

27,2

188
Variable name

Bank debt (1)

Bank debt (2)

Long-term bank debt

Bank debt maturity (1)

Bank debt maturity (2)

Leverage

Ownership structure

Nature of main

shareholder (1)

Nature of main

shareholder (2)

Nature of main

shareholder (3)

Nature of main

shareholder (4)

Nature of main

shareholder (5)

Growth opportunities (1)

Growth opportunities (2)

Deficit of funds

Company size

Bankruptcy risk (1)

Bankruptcy risk (2)

Profitability

Term structure of interest rates

Table I.

Variables definition
Variable measure

Bank debt/total assets

Bank debt/total liabilities

Long-term bank debt/bank debt

Short-term bank debt/bank debt

(Short-term bank debt - variation of working capital)/bank debt

Total liabilities/equity at book value

$\%$ of shares owned by main shareholder

Dummy variable which takes value 1 when main shareholder is a family and 0 otherwise

Dummy variable which takes value 1 when main shareholder is an institutional investor and 0 otherwise

Dummy variable which takes value 1 when main shareholder is a

domestic firm and 0 otherwise

Dummy variable which takes value 1 when main shareholder is a

multinational firm and 0 otherwise

Dummy variable which takes value 1 when main shareholder is a

governmental entity and 0 otherwise

(Market capitalization + total liabilities)/total assets

(Market capitalization)/total equity capital

(Cash dividend + net investment + change in working capital + current portion of long-term debt at the start of the period - cash flow after interest and taxes)/total assets

Ln(total assets)

1.2 (working capital/total assets) +1.4 (retained earnings/total assets) +3.3 (EBIT/total assets) +0.6 (equity capital at market value/total liabilities) +1.0 (sales/total assets)

$\mathrm{Ln}(\mathrm{ROA}+$ (total equity capital/total assets)/standard deviation (ROA))

EBIT/total assets

(Long-term interest rates - short-term interest rates)/long-term

interest rates

Growth rate of GDP per year

where $i$ stands for 1 to 148 for the sample of Chilean firms and 1 to 111 for the Spanish ones; $t$ ranges from 1991 to 2001 for both samples. The $\eta_{i}$ and $\varepsilon_{i t}$ correspond to the individual effect and the stochastic error term, respectively.

We also included time dummy variables (DUMMTEMP) for each of the years in this study, dummy variables for each of the eight industries (DUMMSEC), and dummy variables according to the nature of the main stockholder.

According to our first hypothesis, a positive value for the coefficient of $\beta_{4}$ for Chilean companies and a negative one for Spanish companies should be expected. The second hypothesis requires a positive value for the addition of coefficients $\beta_{4}$ and $\beta_{5}$ for Chilean companies; in the case of Spanish companies, the relationship should be negative. Finally, we used the estimations of $\beta_{2}$ and $\beta_{3}$ to test our third hypothesis.

Additionally, we run the following model only for Spanish companies:

$$
\begin{aligned}
Y_{i, t}= & \beta_{0}+\beta_{1} Y_{i, t}+\beta_{2} O W N 1_{i, t}+\beta_{3}(O W N 1 \times G O I)_{i, t}+\beta_{4} G O_{i, t}+\beta_{5}(G O \times D E F)_{i, t} \\
& +\beta_{6}(G O \times I N S I N V)_{i, t}+\beta_{7} T D E B_{i, t}+\beta_{8} L N T A B_{i, t}+\beta_{9} Z_{i, t}+\beta_{10} R O A_{i, t} \\
& +\beta_{11} T I N T_{i, t}+\beta_{12} G G D P_{i, t}+\beta_{13} D U M S E C+\beta_{14} D U M T E M P+\eta_{i}+\varepsilon_{i, t}
\end{aligned}
$$


In Equation (3) we included the interaction variable that measures the existence of growth opportunities when the main owner is a bank (GO $\times$ INSINV). The rest of the variables were the same as in Equation (2)[7]. Equation (3) enabled us to accept or reject our hypothesis that when banks act as insiders they provide an alternative corporate governance mechanism in place of short-term bank debt to solve the problems of underinvestment and asset substitution.

The main advantage of the panel data methodology is that it allows us to overcome the unobservable and constant heterogeneity of each firm -competitive advantages and strategies, management quality and style, etc. (Himmelberg et al., 1999). Moreover, panel data contains higher informative contents, higher variability, less collinearity between the variables, and higher efficiency. Arellano and Bover (1990) argue that the panel data analysis allows the assessment of the dynamicity of the adjustments and is better in terms of the identification and measurement of those effects that are not observable either with the cross-sectional analysis or the time-series analysis. Nevertheless, we faced the common problem of simultaneity, given that some of the independent variables included in our integrated model - such as growth opportunities, the deficit of funds, ownership, profitability, or the probability of bankruptcy - could be determined simultaneously by the dependent variable.

When the unobserved effect is correlated to independent variables, pooled OLS regression produces estimations that are biased and inconsistent. We can overcome this econometric issue by using either the first differences or the fixed effects (within) estimators (Nickell, 1981). The general approach for estimating models that do not satisfy strict exogeneity is to use a transformation in order to eliminate the unobservable effects and instruments to deal with endogeneity (Wooldrigde, 2002). Thus, we used the two-step system estimator (SE) (Blundell and Bond, 1998) with adjusted standard errors for potential heteroskedasticity as proposed by Blundell and Bond (1998). This econometric method considers the unobserved effect of transforming the variables into first differences, and uses the generalized method of moments (GMM) to deal with endogeneity problems. Those differences are reflected in the quality of the instruments involved (Levine et al., 2000). The existence of weak instruments can lead to a poor asymptotic precision in finite samples (Alonso-Borrego and Arellano, 1999; Blundell and Bond, 1998). Therefore, in our model, it is also necessary to use an estimator that lessens this problem, substituting the specification in differences for the original regression in levels such as the SE (Blundell and Bond, 1998). Performing the model in this way, the SE involves two kinds of equations (simultaneous equations) with their own instruments. The first category of equations is in levels, and its instruments are the lagged differences in the dependent and the independent variables. The second category of equations consists of equations in first differences with the levels of the dependent variable and the independent variables as instruments (Bond, 2002; Wooldrigde, 2002). For our case, by using the GMM method we were able to build instruments for those variables that were potentially endogenous (ownership structure, growth opportunities, deficit of funds, ownership, profitability, and bankruptcy).

To test the model specifications' validity, we used the Hansen/Sargan test of over-identification of restrictions. The first- and second-order serial correlation contrasts were also included in order to test that the differenced error term did not present second-order serial correlation. The Wald test of joint significance of all the independent variables was computed. In addition, we used the adjustment for small samples proposed by Windmeijer (2005) to avoid any potential downward bias in the estimated asymptotic standard errors. 
ARLA

27,2

190

\section{Results}

Descriptive analysis

Our hypotheses imply that the use of short-term bank debt to alleviate underinvestment and asset substitution problems is contingent on the banking regulations governing banks that hold shares in firms. There are statistically significant differences between Chilean and Spanish firms in the volume of debt, the relative importance of bank debt, and in the mix between short- and long-term bank debt. Spanish firms were, in average terms, more leveraged than those in Chile (91 percent for Spanish firms compared to 45 percent for Chilean ones). Spanish firms presented a higher proportion of bank debt, both relative to assets (17 percent as opposed to 12 percent), and relative to total debt (54 percent compared to 41 percent) (see Table II, panel A). The same findings are observed when the median is considered (see Table II, panel B).

Both countries show a high ownership concentration. This fact is characteristic of civil-law bank-based countries. On average, the firm's main stockholder owns more than 40 percent of the stocks: 44.19 percent in Chilean firms and 40.93 percent in Spanish ones. Such a difference is statistically significant.

We observed that on average the proxy for growth opportunities exceeds 1 in both countries. It was higher in Chile than in Spain (1.34 and 1.23, respectively). Chilean firms presented superior ROA than Spanish firms, and higher Altman Z-Score values. Furthermore, Chilean firms achieve an average surplus of 11 percent in the generation of internal funds over total assets, while Spanish firms obtained only 8 percent, explaining why Spanish firms are more leveraged.

The figures in Table II reveal that in most Chilean firms, the main stockholder is either a domestic firm (46 percent) or a mutual fund (40 percent). These data evidence the pyramidal structure of ownership in Chile (Majluf et al., 1998; Lefort and Walker, 1999-2000; Gallego and Loayza, 2000). In the case of Spain, there is no clear pattern in the nature of the main stockholder.

To gain a deeper insight into the descriptive analysis, we divided each of the firm samples, Chile and Spain, using the ratios long-term bank debt to bank debt (LBDBD) and SBDBD. Each sample was divided into three subsamples that contain, respectively: firms with low levels of long-term/short-term bank debt (N-tile 1); firms with medium levels of long-term/short-term bank debt (N-tile 2); and firms with high levels of long-term/short-term bank debt (N-tile 3). To reinforce the results of our variance we just compared the average values of the subsamples with low and high levels of longterm/short-term bank debt for each country (N-tiles 1 and 3) in Table II.

Chilean firms with less short-term bank debt use less bank debt overall, have a higher proportion of long-term bank debt, fewer growth opportunities, and a reduced capacity to generate funds internally, than firms that use a higher proportion of short-term bank debt. In contrast, the Chilean firms that use the most long-term bank debt are more highly leveraged, have a greater proportion of bank debt, fewer growth opportunities, less capacity to generate funds internally, are larger, and less profitable than those that use less long-term bank debt (Table II).

Spanish firms with a lower proportion of short-term bank debt use more bank debt as a whole, have a higher proportion of long-term bank debt, more growth opportunities, generate less funds internally, are larger and more profitable than firms that use more short-term bank debt (Table II). The results of the variance analysis indicate that the Chilean firms that use more short-term and less long-term bank debt present the best growth opportunities. However, among Spanish firms, it is those that least use short-term bank debt that present the best growth opportunities. This finding 


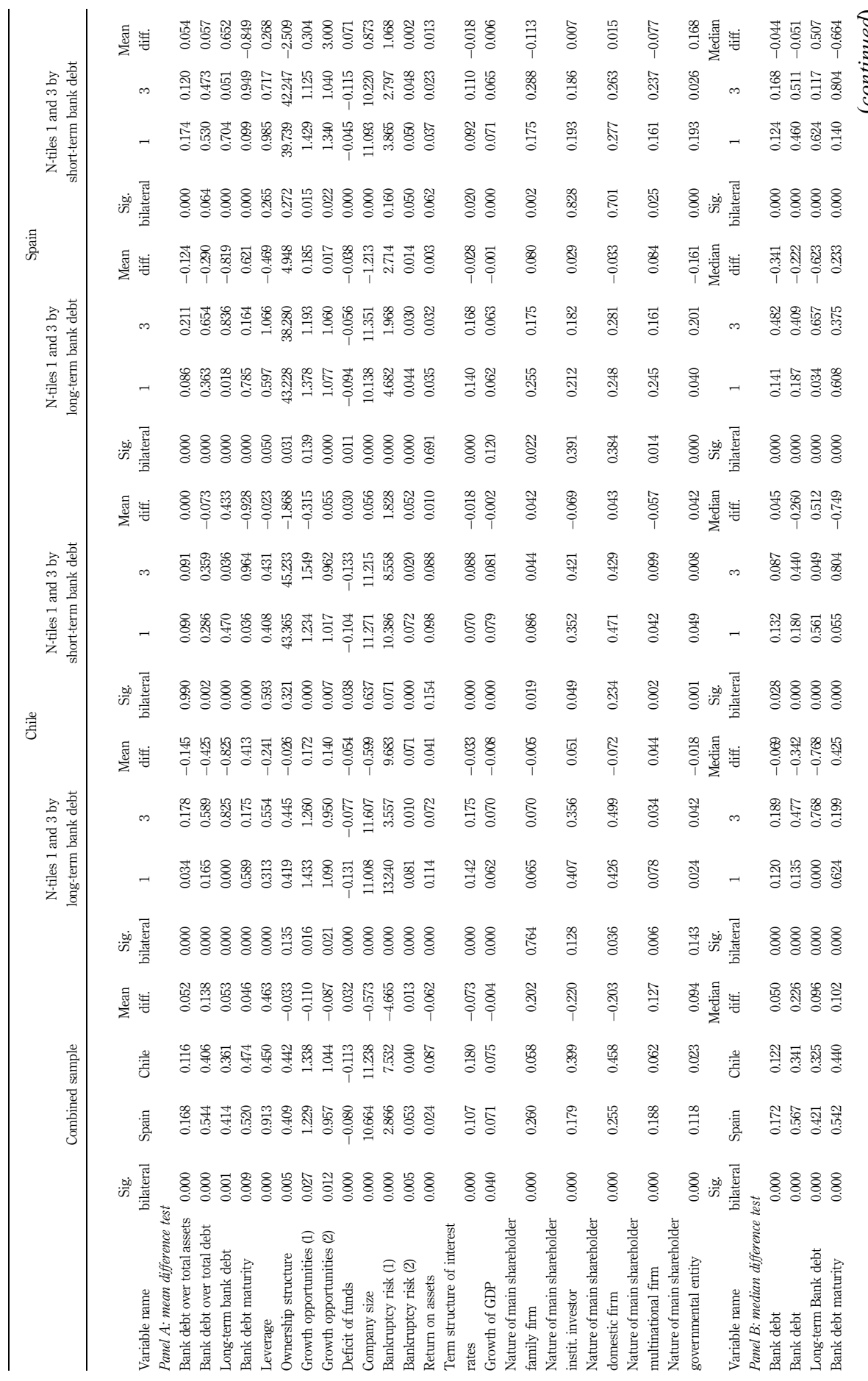

Bank-debt maturity

191

Table II.

Tests of mean differences and medians differences among the variables for Chilean and Spanish samples 
ARLA

27,2

192

Table II.

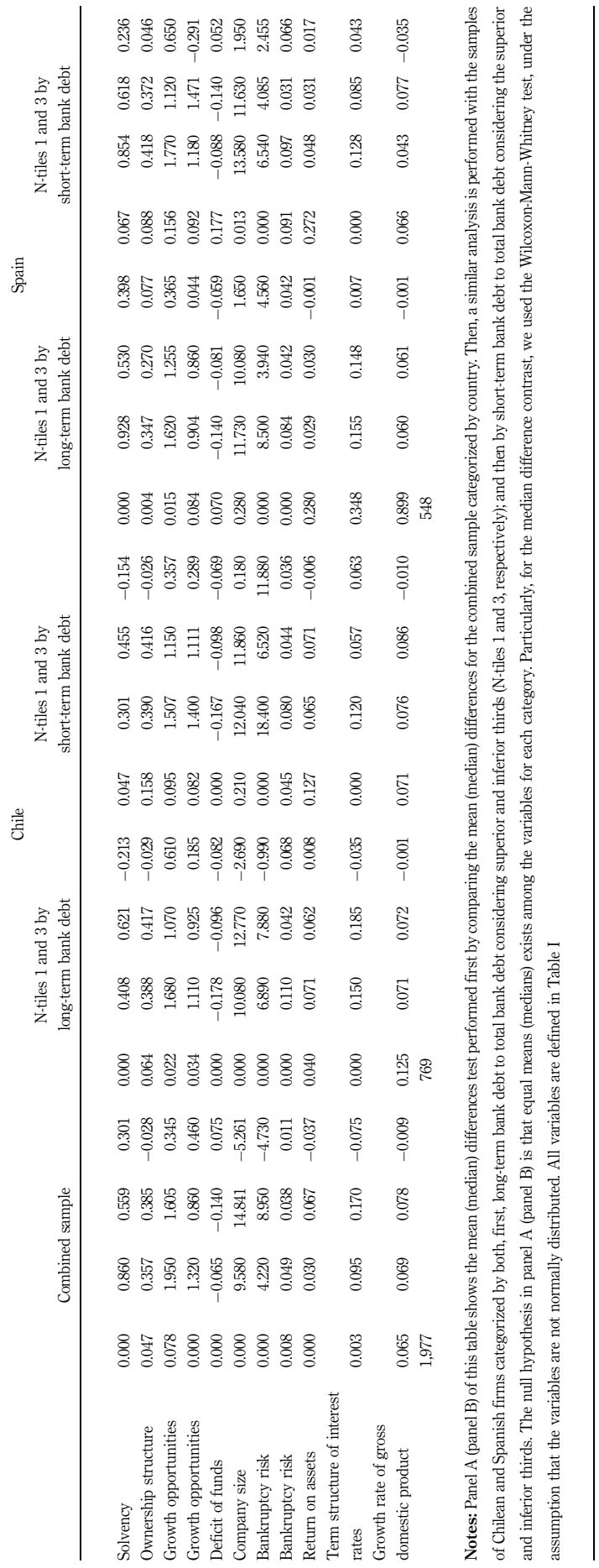


is important evidence of the different role that bank debt-maturity plays in Spain and Chile in the financing of growth opportunities.

Banking regulation about controlling stakes in non-financial firms influences the way non-financial firms use external funds to finance growth opportunities. Those companies internally controlled by a bank suffer less financial constraints and liquidity risk than those companies with no ownership ties with a bank.

Table III describes the correlation coefficients among the variables included in the empirical analysis. For the sample as a whole, short-term bank debt is negatively correlated with the ownership structure, the deficit of funds, the term structure of interest rates, and the growth rate of the GDP. Growth opportunities, company size, and the two proxies of bankruptcy risk are positively correlated with the proportion of short-term bank debt (see Table III).

\section{Regression analysis}

We ran a regression analysis for each country[8]. Tables IV and V show the results corresponding to the hypotheses that relate growth opportunities and ownership structure to bank debt-maturity in each institutional environment. The Wald tests to determine the significance of both the model and the dummies are statistically significant[9]. The Hansen/Sargan test allows us to accept the null hypothesis that the model is correctly identified.

When the financial system is bank-based, the relationship between bank-debt maturity and growth opportunities depends on the role that banks play within the system. If banks are simultaneously internal stockholders and lenders, bank-debt maturity loses its value as a signal of the quality of the growth opportunities and its power to discipline the managers. Instead, banks can control firm management through their stockholdings.

Our results revealed differences between the behavior of Chilean and Spanish firms[10]. Chilean firms showed a negative relation between a firm's growth opportunities and bank debt-maturity; the relation is even stronger when the firm needs external funds. Chilean firms that need external funds to finance their growth opportunities use short-term bank debt. In contrast, in the Spanish firms, we observed a positive relation between the existence of growth opportunities and bank debt-maturity. All those companies controlled by a financial institution use bank funds to finance their growth opportunities with longer maturities. This result (Table IV) confirms the exploratory results of the variance analysis and supports our $H 1$ and $H 2$.

In Spain, banks' ability to become internal stockholders makes it unnecessary for firms under bank control to use bank debt-maturity to reduce their underinvestment problems. However, in Chile, where banks cannot become internal stockholders, managers use bank debt-maturity to resolve their underinvestment problems. Chilean firms use short-term bank debt as a sign that they have profitable growth opportunities. In these firms, the greater the agency problems caused by the growth opportunities and the need for external finance $(\mathrm{GO}+\mathrm{GO} \times \mathrm{DEFI})$, the greater the recourse to short-term bank debt as a corporate governance mechanism. In contrast, the managers of Spanish firms under the control of a bank do not need to issue short-term bank debt to solve this type of agency problem. Spanish firms can use their greater ownership concentration and the participation of the lending banks in their equity as alternative governance mechanisms. Therefore, it appears that the institutional environment of each country does affect firms' willingness to finance their growth opportunities with bank debt. 


\begin{abstract}
ARLA
27,2
\end{abstract}

194

Table III.

Correlation matrix

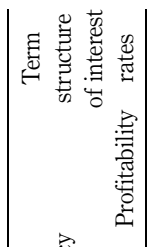

善 衰势 ๓

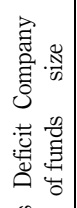

:

旁要 $\widehat{0}$ ิㅡㅇ

害衰意

㓤

范莒意

㮍莺意

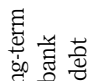
s

营莺

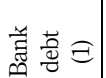

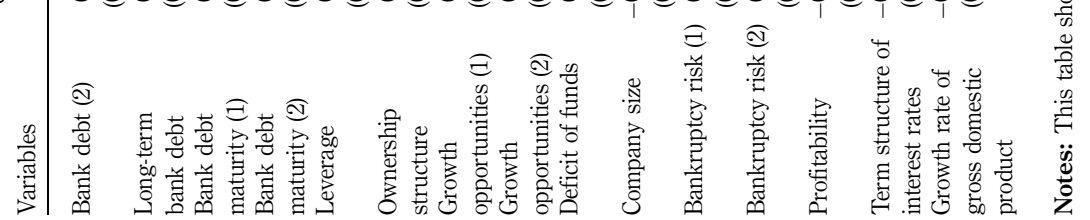

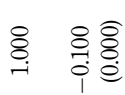

\&

\&

\&

\& \%

\&

\&

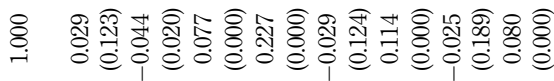

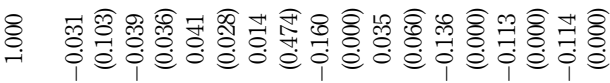

\&

\&

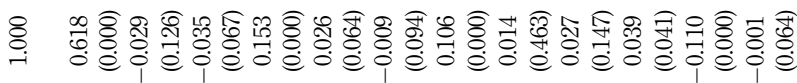

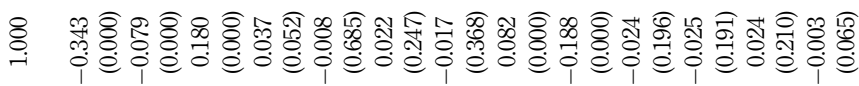

\&

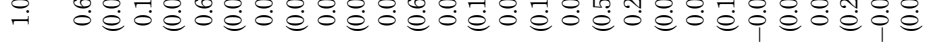
品 


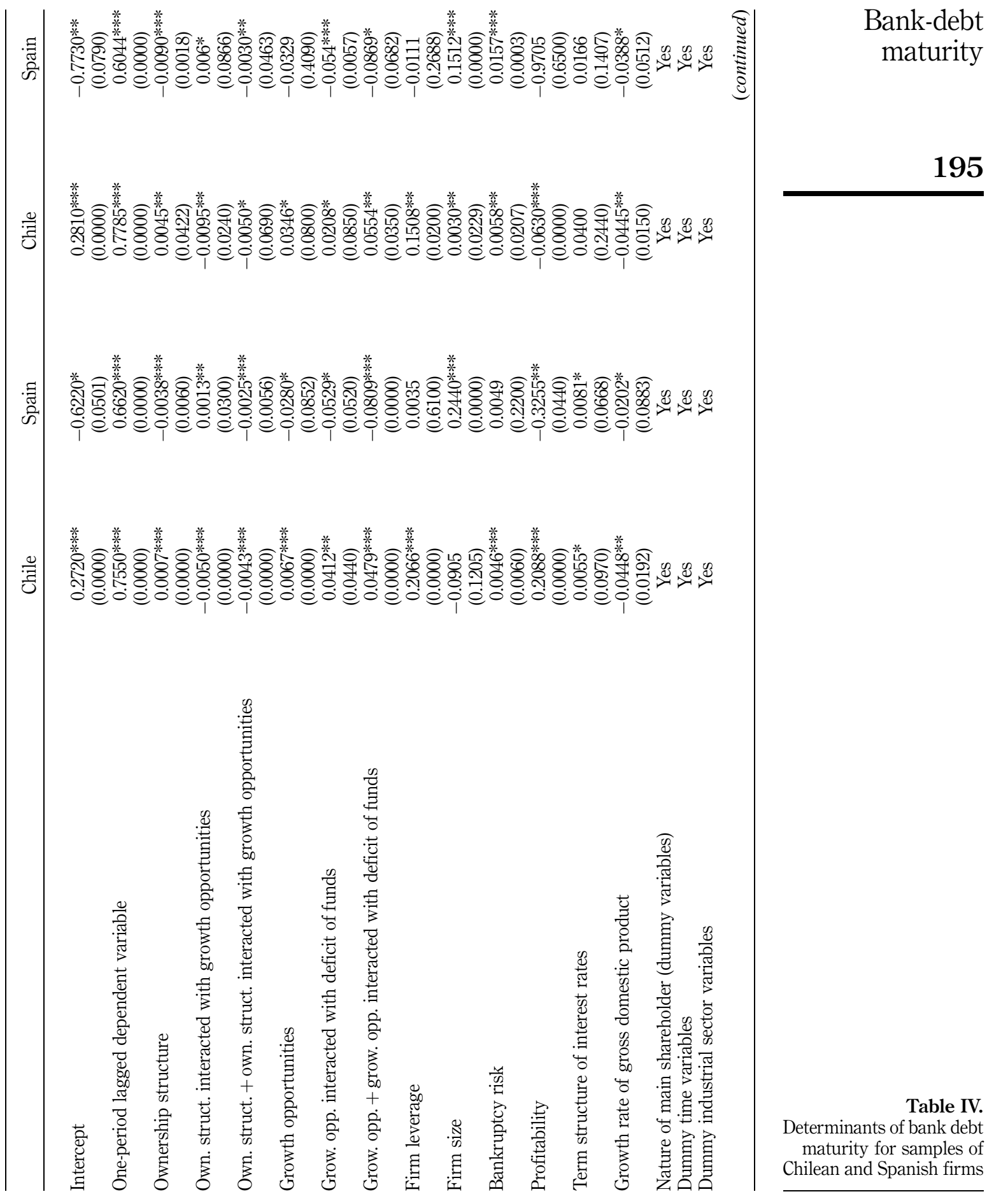


ARLA

27,2

196

Table IV.

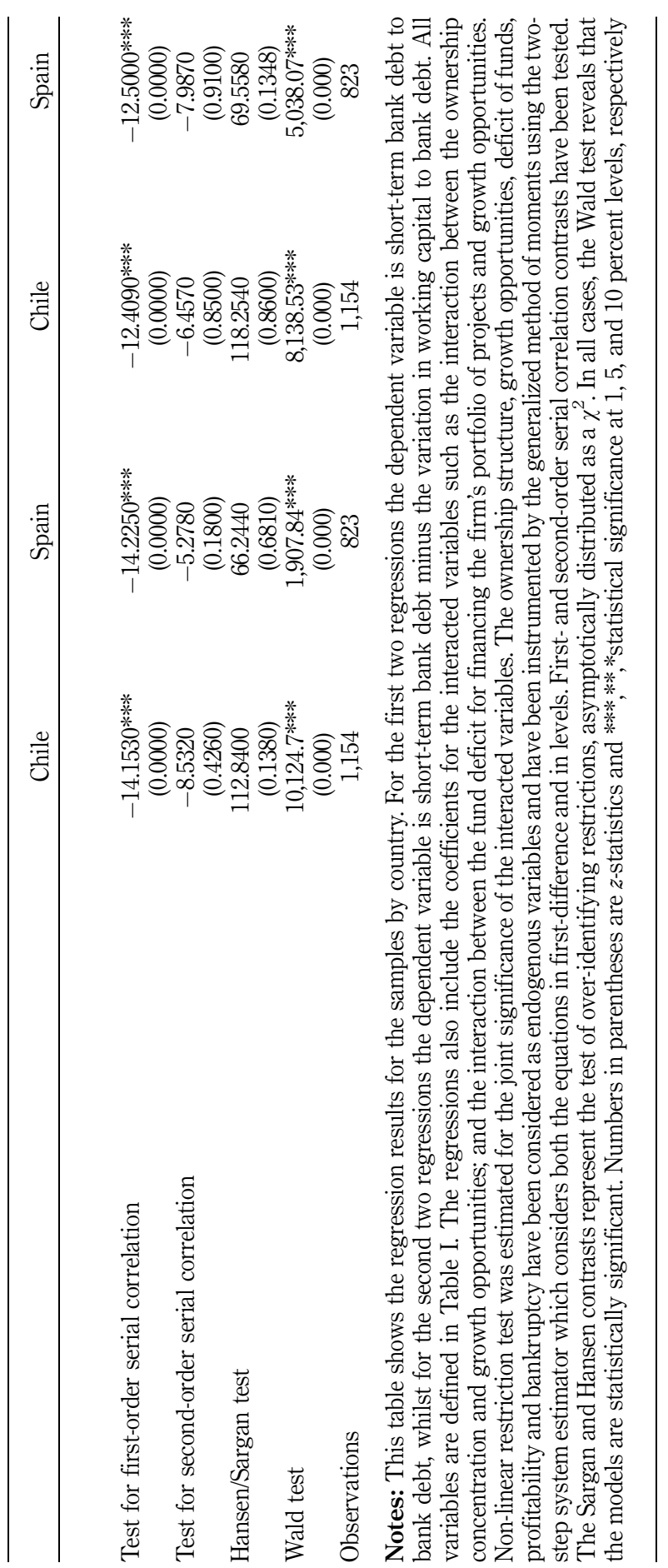




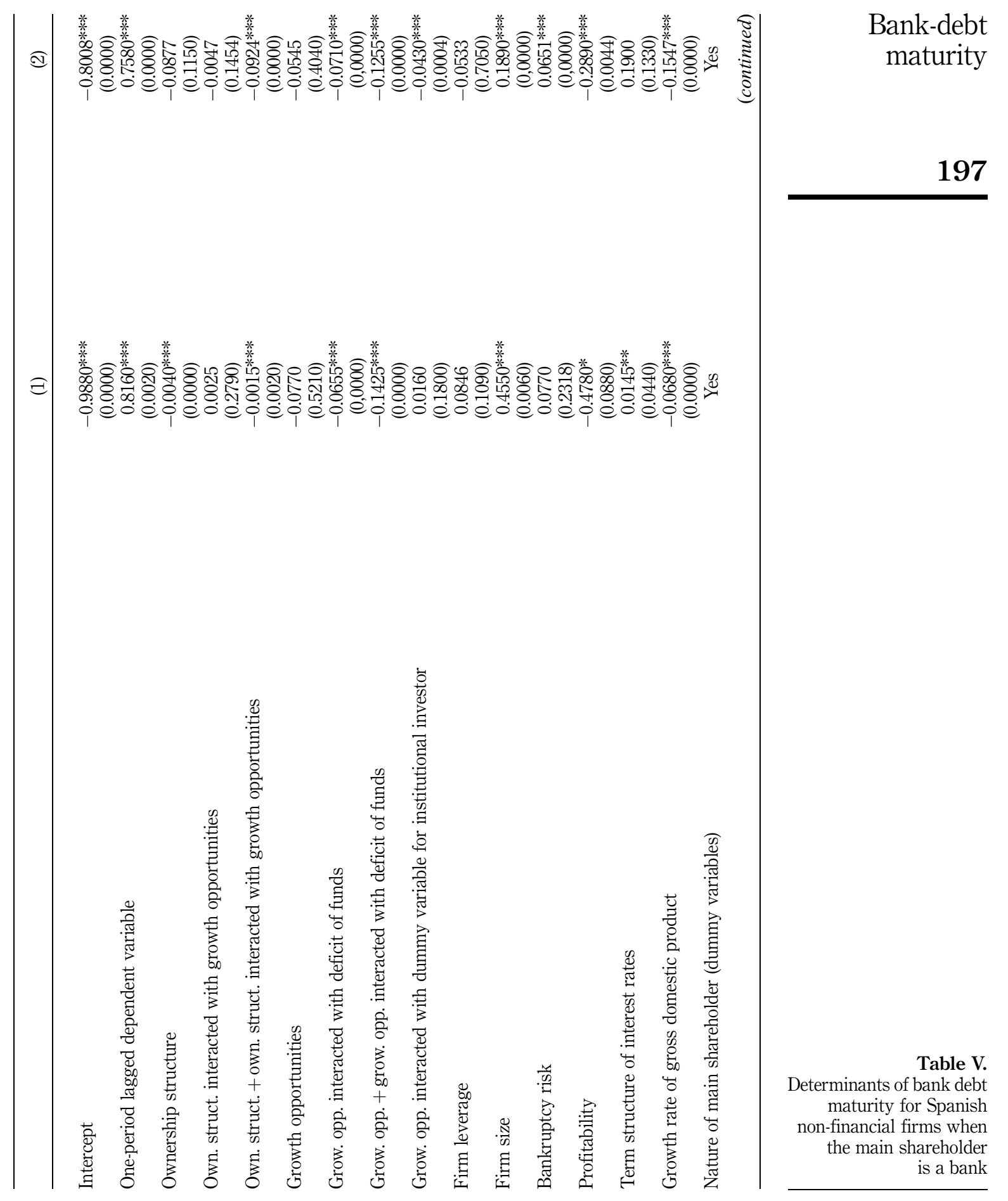


ARLA

27,2

198

Table V.

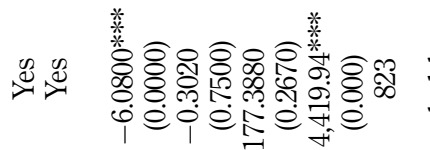

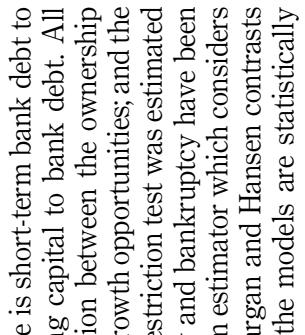

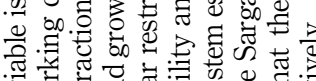

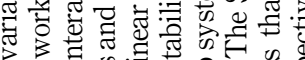

苟. .

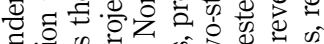

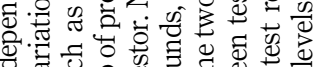

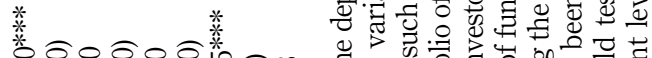

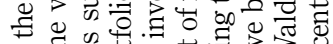

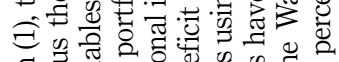

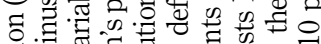

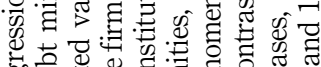

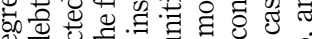
讨

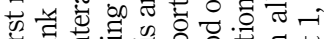

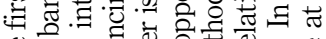
Eี

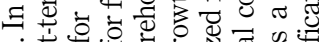

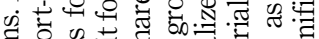

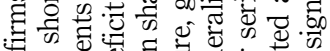

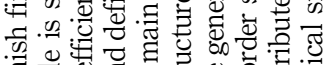

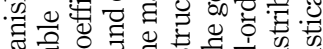

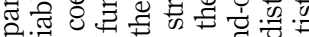

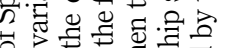

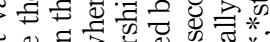
च

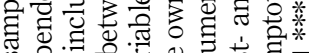

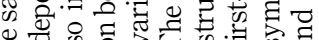

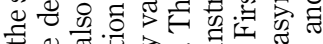

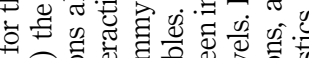

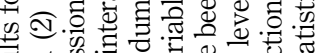
के

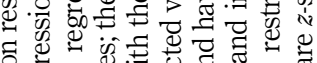
ธิ W

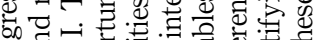

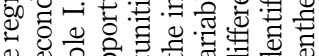

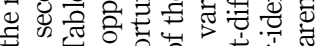

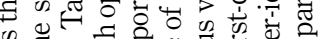

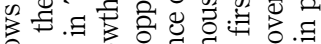

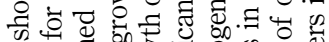

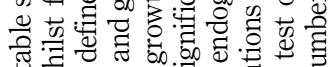

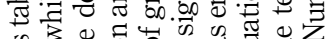

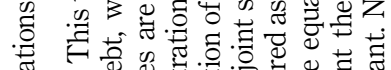

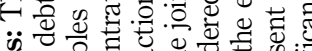

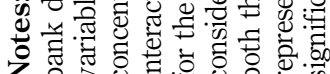


According to previous research, between 1990 and 1999, the Chilean financial system underwent various structural modifications where firms with good ratings were allowed to issue ADRs and to hold external financial assets in their portfolios (Gallego and Loayza, 2000). Consequently, the freedom of capital movements in Chile during the 1990s, along with the banking regulation that forbids Chilean banks to own shares in non-financial firms, help to explain our results.

We observed that, as the ownership concentration of Chilean firms increases, they use more short-term bank debt (Table IV). This result is dissimilar to that obtained for Spanish firms and confirms our third hypothesis; the differences we observe are a consequence of the different bank regulations, specifically regarding ownership of non-financial firms by banks.

Table $\mathrm{V}$ shows the results when we introduce the interacted variable $\mathrm{GO} \times \mathrm{INSINV}$ to consider the presence of banks as main shareholders of non-financial firms. If the bank can simultaneously act as lender and internal stockholder (as in Spanish firms), we observe that firms with growth opportunities reduce their use of short-term bank debt. Bank ownership and short-term bank debt become an alternative governance mechanism to mitigate the agency problems.

\section{Robustness checks}

Additionally, we reran the regressions for Tables IV and V but this time with the alternative proxy for growth opportunities measured as the firm's market capitalization over the equity capital. The findings are both robust and consistent to this alternative measure. In the same vein, no matter which variable for bank debt-maturity was used (SBDBD or SBDWBD), the results were also consistent. For instance, the robustness checks reveal that the public Chilean firms with growth opportunities use short-term bank debt as a corporate governance mechanism, whilst Spanish firms use less short-term bank debt. Additionally, we observed that whenever firms in Chile account with a funds deficit, as well as future growth opportunities, the bank debt maturity decreases in order to mitigate the moral hazard problems. This finding is the opposite for the sample of Spanish firms. We also observe that when banks are forbidden to hold equity stakes in companies, there is a negative relationship between ownership concentration and bank debt maturity. All these findings support our research hypotheses (see Table VI). For the particular case of Spanish firms where banks can hold equity stakes in those firms financed by the bank, we observed that when the company has growth opportunities and a concentrated ownership structure, the short-term bank debt decreases. The same relationship is observed when the firm presents growth opportunities and the financing bank is already a shareholder. In other words, the findings are consistent in supporting the idea that when the bank is a shareholder, it can exercise tight control over the firm through its voting rights; and therefore, the firm can substitute the short-term bank debt for debt with longer maturities (see Table VII).

\section{Conclusions}

We focussed our efforts on testing whether firms' bank debt-maturity decisions are related to the existence of growth opportunities, the ownership structure, or the characteristics of the legal and institutional environment where firms operate. In particular, we analyzed to what extent the participation of banks as internal stockholders of non-financial firms modifies the role of bank debt-maturity in solving asymmetric information and agency problems. 

ARLA
27,2

200

Table VI.

Determinants of bank debt maturity for samples of Chilean and Spanish firms

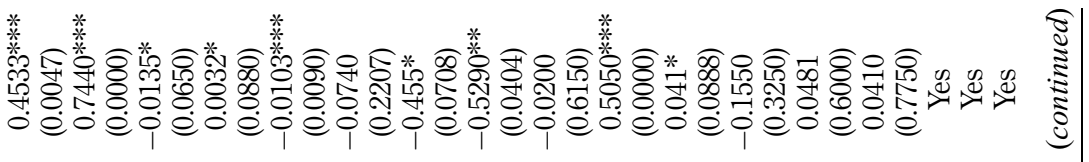

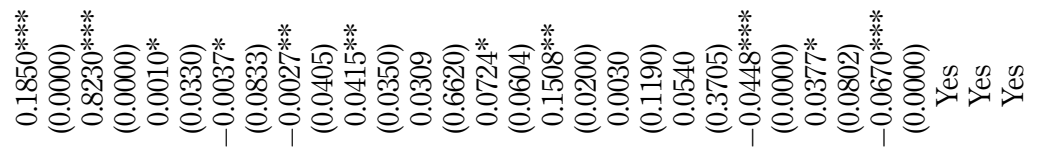

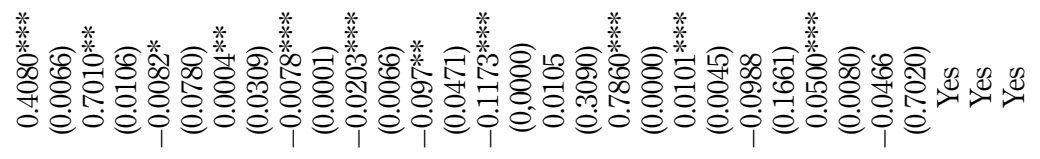

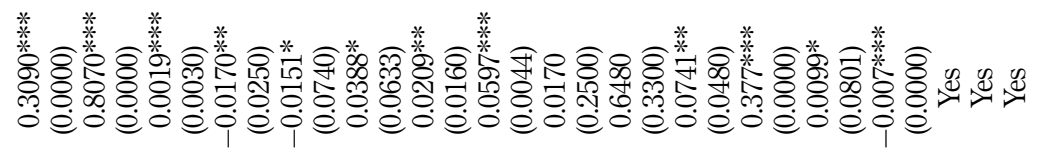

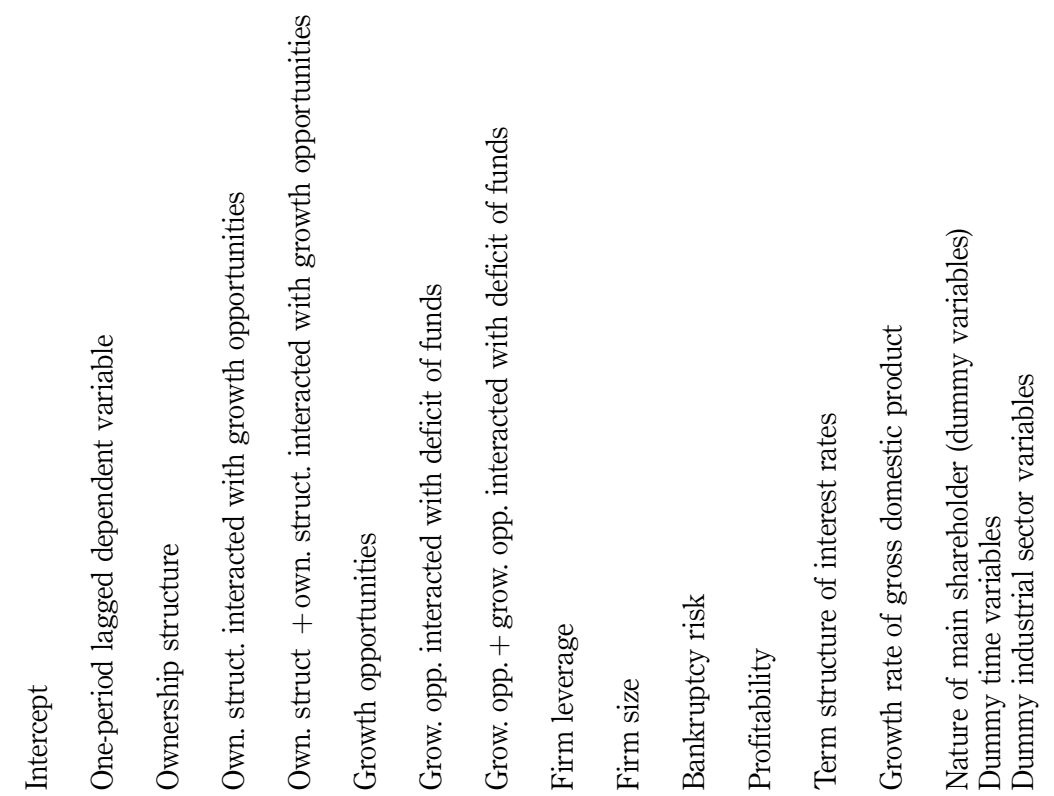




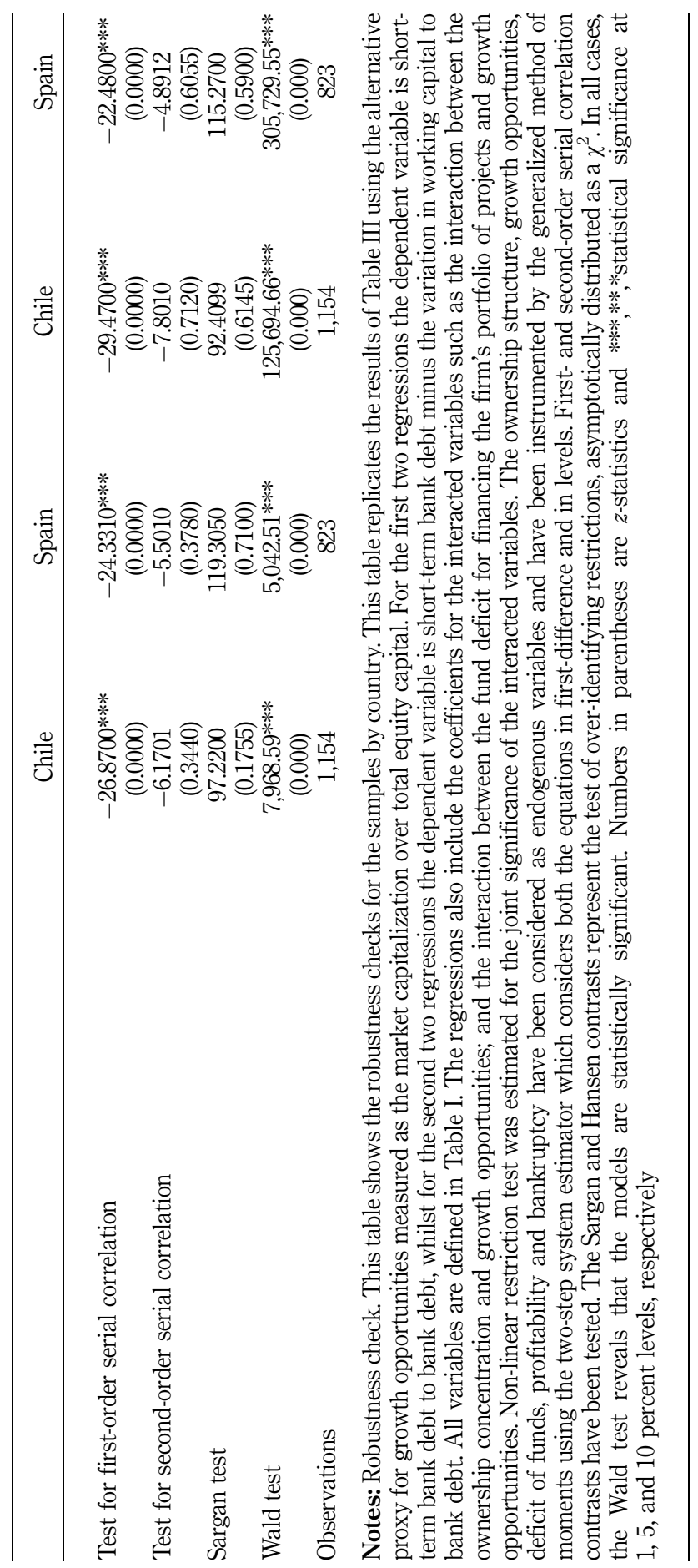

Bank-debt maturity

201

Table VI. 
ARLA

27,2

202

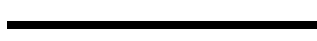

Table VII.

Determinants of bank debt maturity for

Spanish non-financial firms Chen the main shareholder is a bank

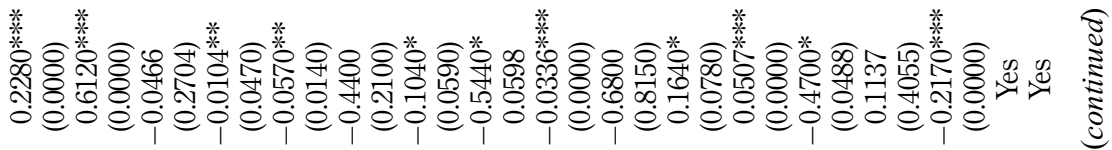

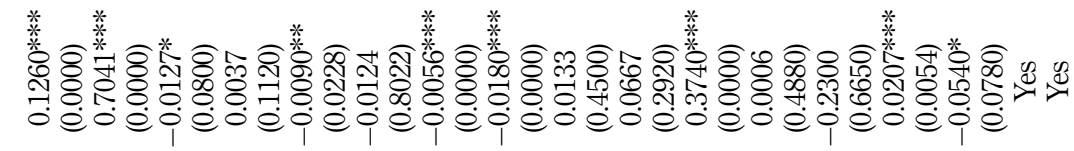

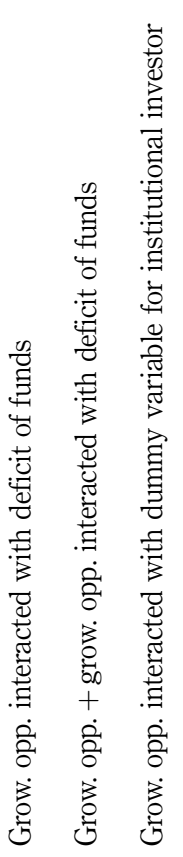

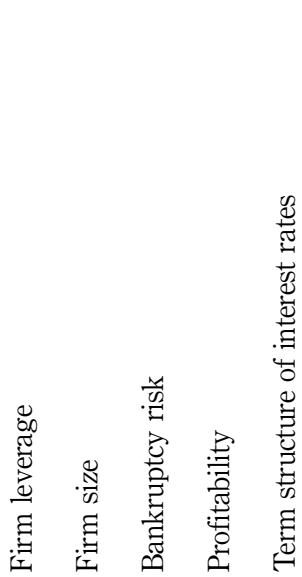

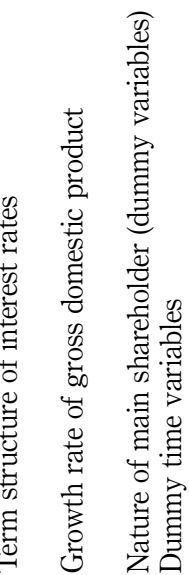




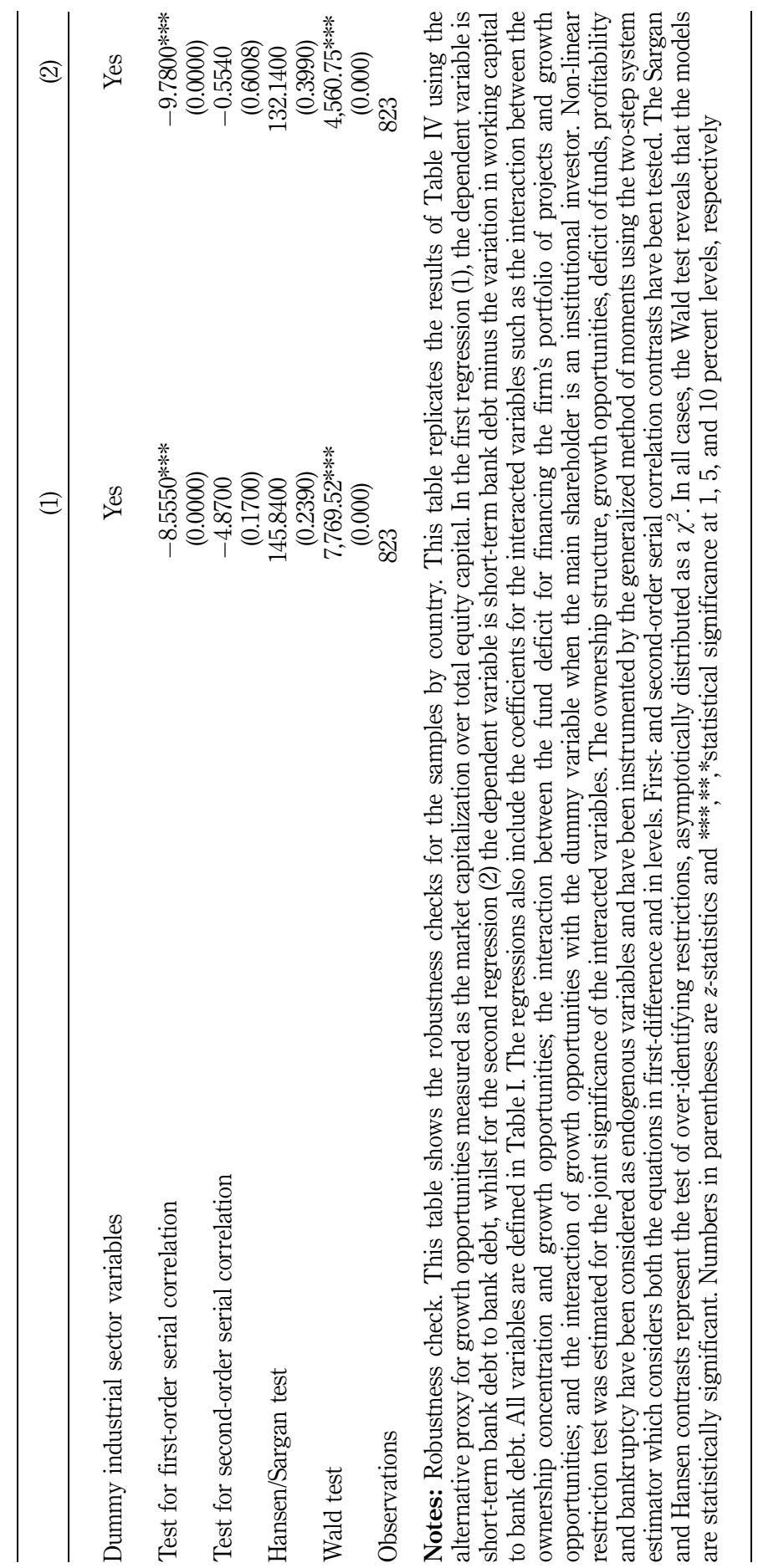

Bank-debt maturity

203

Table VII. 
ARLA

27,2

204
For this purpose, we used a sample of Chilean and Spanish firms. Regression analysis shows that Spanish firms with growth opportunities do not appear to resolve their underinvestment problems by shortening bank debt-maturity. The banks' participation in the ownership of the firms acts as a substitute for short-term bank debt as a governance mechanism for resolving information asymmetry problems. In Chilean firms, in contrast, where banks cannot be internal stockholders, managers are forced to use bank debt-maturity to resolve their underinvestment problems. This problem is more severe the greater the need for external funds. Thus, whereas Chilean firms with deficit and growth opportunities resort to short-term bank debt, in Spain, the opposite takes place. In Spain, the combination of a high ownership concentration and the banks' participation in the equity of the firms to which they lend are the elements acting as efficient governance mechanisms, whereas in Chile, it is the combination of high ownership concentration and bank debt.

In sum, we have seen that bank debt decisions are dependent on the characteristics of the institutional environment in which firms operate, and that these environments evolve differently depending on the decisions adopted by the regulators. The role of debt-maturity to solve underinvestment and asset substitution problems is contingent on bank regulation. On the other hand, in those countries where banks have limitations on their control of non-financial firms, firms will use shorter bank debt-maturities to finance their growth opportunities.

Our recommendation for policy makers is that banks should reduce their controlling stakes in non-financial firms to avoid risk concentration and conflict of interest when they are simultaneously internal shareholders and the main lenders of a non-financial company. Thus, banks should decide on financing based on the quality of firms' growth opportunities. Such behavior would improve firms' access to external funds independently of their banking ownership ties. As policy makers introduce higher degrees of competition in the capital markets, the companies with the best investment projects will benefit from higher availability of funds at a lower cost.

The particular evolutionary process of the financial system in each country may lead to market imperfections - such as information asymmetries and agency costs - to have a distinct influence on both firms' investments and in the use of bank debtmaturity for managers' control and supervision.

\section{Notes}

1. The introduction of the institutional setting in the analysis is what Stulz (2006) calls the twin agency problem.

2. The FECU is the "Ficha Estadística Codificada Uniforme" published by the "Superintendencia de Valores and Seguros" in Chile.

3. We appreciate the comments of an anonymous referee on this point.

4. Other measures of ownership concentration calculated were the percentage of stocks in the hands of the two main stockholders as well as in hands of the five main stockholders.

5. Additionally, as an alternative measure for growth opportunities, we used the investment in assets in time $t+1$ but this measure was insignificant in our regression outputs. We consider that the two proxies (Q and Q2) used are suitable in this study. These measures are also supported by a number of other works developed with samples of firms from Chile and Spain such as Azofra et al. (2004, 2007), Saona and Vallelado (2010), Saona (2010), and Jara et al. (2012), among others.

6. We are grateful for the comments of an anonymous referee in including an alternative variable to measure the bankruptcy risk. Nevertheless, after the regression outputs, we 
decided to use the Altman $Z$-Score because the proxy used according to Laeven and Levine (2009) was insignificant. Additionally, the Altman Z-Score has been used successfully in both the Chilean and the Spanish contexts in previous research (Azofra et al., 2004, 2007; Jara et al., 2012; Saona, 2010; Saona and Vallelado, 2010).

7. As a robustness check, we have run alternative regressions using long-term bank debt to bank debt as the dependent variable. The presence of serial correlation invalidates the results.

8. Moreover, we ran a regression analysis for a sample that includes both countries' companies with a dummy variable that takes the value of one for Chilean companies and zero for Spanish companies. The results confirm that there are differences between Chilean and Spanish companies in bank debt-maturity decisions.

9. In order to simplify, we have omitted the values of these tests in the corresponding tables. We have only included those models that are statistically significant. The tests performed and the values obtained are available from the authors on request. The Wald test has been performed to check the combined significance of parameters; the significance of temporary dummy variables; the significance of industry variables; and the significance both of temporary dummy variables and of industry.

10. We only report GMM system estimators because they are consistent and the most efficient. Our results with GMM first difference estimators are qualitatively similar.

\section{References}

Akerlof, G. (1970), “The market for 'lemons': quality and the market mechanism”, The Quarterlv Iournal of Economics, Vol. 84 No. 3, pp. 488-500.

Alcock, J., Finn, F. and Tan, K.J.K. (2012), "The determinants of debt maturity in Australian firms", Accounting \& Finance, Vol. 52 No. 2, pp. 313-341.

Alonso-Borrego, C. and Arellano, M. (1999), "Symmetrically normalized instrumental variable estimation using panel data", Journal of Business \& Economic Statistics, Vol. 17 No. 1, pp. 36-49.

Altman, E. (1968), "Financial ratios, discriminant analysis and the prediction of corporate bankruptcy", The Iournal of Finance, Vol. 23 No. 4, pp. 589-609.

Antoniou, A., Guney, Y. and Paudyal, K. (2008), "The determinants of capital structure: capital market-oriented versus bank-oriented institutions", Journal of Financial and Quantitative Analysis, Vol. 43 No. 1, pp. 59-92.

Arellano, M. and Bover, O. (1990), "La econometría de datos de panel", Investigaciones Económicas (Segunda Época), Vol. 14 No. 1, pp. 3-45.

Azofra, V., Saona, P. and Vallelado, E. (2004), "Estructura de propiedad y oportunidades de crecimiento como determinantes del endeudamiento de las empresas chilenas", Revista ABANTE, Vol. 7 No. 2, pp. 105-145.

Azofra, V., Saona, P. and Vallelado, E. (2007), "Oportunidades de crecimiento y estructura de propiedad como determinantes del apalancamiento de las empresas españolas", Spanish Journal of Finance and Accounting, Vol. XXXVI No. 113, pp. 11-30.

Barclay, M.J. and Smith, C.W. (1999), "The capital structure puzzle: another look at the evidence", Journal of Applied Corporate Finance, Vol. 12 No. 1, pp. 8-20.

Barclay, M., Smith, C. and Watts, R. (1995), "The determinants of corporate leverage and dividend policies", Journal of Applied Corporate Finance, Vol. 7 No. 4, pp. 4-19.

Bartholdy, J., Boyle, G. and Stover, R. (1997), "Corporate capital structure and regulation of bank equity holdings: some international evidence", Multinational Finance Journal, Vol. 1 No. 1, pp. 60-80.

Beck, T. and Levine, R. (2002), "Industry growth and capital allocation: does having a market or bank-based system matter?”, Iournal of Financial Economics, Vol. 64 No. 2, pp. 147-180. 
ARLA

27,2

206
Berger, A., Espinosa, M., Frame, W. and Miller, N. (2005), "Debt maturity, risk, and asymmetric information”, The Iournal of Finance, Vol. 60 No. 6, pp. 2895-2923.

Bharadwaj, A. and Shivdasani, A. (2003), "Valuation effects of bank financing in acquisitions", Journal of Financial Economics, Vol. 67 No. 1, pp. 113-148.

Blundell, R. and Bond, S. (1998), "Initial conditions and moment restrictions in dynamic panel data models", Iournal of Econometrics, Vol. 87 No. 1, pp. 115-143.

Bond, S. (2002), "Dynamic panel data models: a guide to micro data methods and practice", Portuguese Economic Iournal, Vol. 1 No. 2, pp. 141-162.

Chen, S., Ho, K. and Yeo, G. (1999), "The determinants of debt maturity: the case of bank financing in Singapore", Review of Quantitative Finance and Accounting, Vol. 12 No. 4, pp. 341-350.

Cuñat, V. (1999), "Determinantes del plazo de endeudamiento de las empresas españolas", Investigaciones Económicas, Vol. 23 No. 3, pp. 351-392.

De Andrés, P., Azofra, V. and Rodríguez, J. (2000), "Endeudamiento, oportunidades de crecimiento y estructura contractual: un contraste empírico para el caso español", Investigaciones Económicas, Vol. 24 No. 3, pp. 641-679.

Demirgüç-Kunt, A. and Maksimovic, V. (1999), "Institutions, financial markets and firm's choice of debt maturity", Journal of Financial Economics, Vol. 54 No. 3, pp. 295-336.

Denis, D. and Mihov, V. (2003), "The choice among bank debt, non-bank private debt and public debt: evidence from new corporate borrowings", Iournal of Financial Economics, Vol. 70 No. 1, pp. 3-28.

Douglas, A.V.S. (2009), "Interactions between corporate agency conflicts", The Financial Review, Vol. 44 No. 2, pp. 151-178.

Flannery, M. (1986), "Asymmetric information and risky debt maturity choice", Iournal of Finance, Vol. 41 No. 1, pp. 19-38.

Gallego, F. and Loayza, N. (2000), "Financial structure in Chile: macroeconomic development and microeconomic effects”, Economía Chilena, Vol. 3 No. 2, pp. 5-30.

Goyal, V., Lehn, K. and Racic, S. (2002), "Growth opportunities and corporate debt policy: the case of US defense industry", Iournal of Financial Economics, Vol. 64 No. 1, pp. 35-59.

Hadlock, C. and James, C. (2002), "Do banks provide financial slack?", The Iournal of Finance, Vol. 57 No. 3, pp. 1833-1419.

Hart, O. and Moore, J. (1995), "Debt and seniority: an analysis of the role of hard claims in constraining management", American Economic Review, Vol. 85 No. 3, pp. 567-585.

Himmelberg, C., Hubbard, R. and Palia, D. (1999), "Understanding the determinants of managerial ownership and the link between ownership and performance", Journal of Financial Economics, Vol. 53 No. 3, pp. 353-384.

Hovakimian, A., Opler, T. and Titman, S. (2001), "The debt-equity choice", Journal of Financial and Quantitative Analvsis, Vol. 36 No. 1, pp. 1-24.

Jara, M., Moreno, M. and Saona, P. (2012), "Non-linear relationship between growth opportunities and bank debt: a panel data analysis of Chilean firms", Academia, Revista Latinoamericana de Administración, Vol. 50 No. 1, pp. 44-65.

Jensen, M. and Meckling, W. (1976), "Theory of the firm: managerial behaviour, agency cost and ownership structure”, Journal of Financial Economics, Vol. 3 No. 4, pp. 305-360.

Johnson, S. (1997), "An empirical analysis of the determinants of corporate debt ownership structure”, Lournal of Financial and Quantitative Analvsis, Vol. 32 No. 1, pp. 47-69.

Johnson, S. (2003), "Debt maturity and the effects of growth opportunities and liquidity risk on leverage", The Review of Financial Studies, Vol. 16 No. 1, pp. 209-236. 
King, R.G. and Levine, R. (1993), "Finance and growth: Schumpeter might be right", Quarterlv Journal of Economics, Vol. 108 No. 3, pp. 717-717.

La Porta, R., Lopez-De-Silanes, F., Shleifer, A. and Vishny, R. (1997), "Legal determinants of external finance", The Iournal of Finance, Vol. 52 No. 3, pp. 1131-1150.

Laeven, L. and Levine, R. (2009), "Bank governance, regulation and risk taking”, Journal of Financial Economics, Vol. 93 No. 2, pp. 259-275.

Lefort, F. and Walker, E. (1999-2000), "Ownership and capital structure of Chilean conglomerates: facts and hypotheses for governance”, Revista ABANTE, Vol. 3 No. 1, pp. 3-27.

Levine, R., Loayza, N. and Beck, T. (2000), "Financial intermediation and growth: causality and causes", Journal of Monetary Economics, Vol. 46 No. 1, pp. 31-77.

Majluf, N., Abarca, N., Rodríguez, D. and Fuentes, L. (1998), "Governance and ownership structure in Chilean economic groups", Revista ABANTE, Vol. 1 No. 1, pp. 111-139.

Morgado, A. and Pindado, J. (2003), "The underinvestment and overinvestment hypothesis: an analysis using panel data", European Financial Management, Vol. 9 No. 2, pp. 163-177.

Myers, S. (1977), "Determinants of corporate borrowing”, Lournal of Financial Economics, Vol. 5 No. 2, pp. 147-175.

Myers, S. and Majluf, N. (1984), "Corporate financing and investment decisions when firms have information that investors do not have", Lournal of Financial Economics, Vol. 13 No. 2, pp. 187-221.

Nickell, S. (1981), "Biases in dynamic models with fixed effects", Econometrica, Vol. 49 No. 6, pp. 1417-1426.

Ozkan, A. (2002), "The determinants of corporate debt maturity: evidence from UK firms", Applied Financial Economics, Vol. 12 No. 1, pp. 19-24.

Rajan, R. (1992), "Insiders and outsiders: the choice between informed and arm's-length debt", Journal of Finance, Vol. 47 No. 4, pp. 1367-1400.

Saona, P. (2010), "Growth opportunities as determinants of the partial adjustment toward target debt ratio: evidence for the Chilean case", International Review of Business and Finance, Vol. 2 No. 2, pp. 179-207.

Saona, P. and Vallelado, E. (2010), "Is the use of bank debt as a governance mechanism conditioned by the financial system? The cases of Chile and Spain", Applied Economics, Vol. 42 No. 13, pp. 1709-1726.

Shleifer, A. and Vishny, R. (1992), "Liquidation values and debt capacity: a market equilibrium approach”, The Iournal of Finance, Vol. 47 No. 4, pp. 1343-1366.

Shyam-Sunder, L. and Myers, S. (1999), "Testing static tradeoff against pecking order models of capital structure”, Iournal of Financial Economics, Vol. 51 No. 2, pp. 219-244.

Smith, C. and Warner, J. (1979), "On financial contracting: an analysis of bond covenants", Journal of Financial Economics, Vol. 7 No. 2, pp. 117-161.

Sogorb, F. and López, J. (2005), "How SME uniqueness affects capital structure: evidence from a 1994-1998 Spanish data panel”, Small Business Economics, Vol. 25 No. 5, pp. 447-457.

Stulz, R. (2006), "Presidential address: the limits of financial globalization", Journal of Finance, Vol. 4 No. 6, pp. 1595-1639.

Vallelado, E. and Saona, P. (2011), "An integrated model of capital structure to study the differences in the speed of adjustment to target long term debt ratio among developed countries", International Journal of Banking. Accounting and Finance, Vol. 3 No. 4, pp. 258-293.

Windmeijer, F. (2005), "A finite sample correction for the variance of linear efficient two-step GMM estimators”, Journal of Econometrics, Vol. 126 No. 1, pp. 25-51.

Wooldrigde, J. (2002), Econometric Analysis of Cross Section and Panel Data, The MIT Press, London. 
ARLA

27,2

208
Yosha, O. (1995), "Information disclosure costs and the choice of financing source", Iournal of Financial Intermediation, Vol. 4 No. 1, pp. 3-20.

Zou, H. and Adams, M.B. (2009), “Corporate insurance and debt: the case of China”, Lournal of Applied Corporate Finance, Vol. 21 No. 1, pp. 87-89.

\section{About the authors}

Dr Paolo Saona is an Assistant Professor of Finance at the Saint Louis University's Madrid Campus in Spain. He received his $\mathrm{PhD}$ at Universidad de Valladolid, Spain, and his MBA and BSc in Business at the Austral University of Chile. He is an Active Researcher and has published his works in several national and international academic journals such as the Applied Economics, the Spanish Journal of Finance and Accounting, ABANTE and Research Management, among others. His research fields are corporate finance (basically, capital structure decisions), corporate governance, and financial systems. He has also served as a Reviewer for international journals. Dr Paolo Saona is the corresponding author and can be contacted at: psaonaho@slu.edu

Eleuterio Vallelado is a Professor of Finance at the Universidad de Valladolid. He obtained his Bachelor's Degree in Economics and Business and his $\mathrm{PhD}$ from the Universidad de Valladolid, Spain and MBA from Stern School of Business, New York University, USA. He has published widely in corporate finance, banking and behavioral finance areas. Author of several books, his articles can be found in Journal of Banking and Finance, Applied Economics, Financial Review, ABANTE, Spanish Review of Finance and Accounting, Universia Business Review, Cuadernos de Economía y Dirección de Empresas, among others. His research interests include: corporate finance, corporate governance in banks, and behavioral finance.

To purchase reprints of this article please e-mail: reprints@emeraldinsight.com Or visit our web site for further details: www.emeraldinsight.com/reprints 